\title{
Evaluated Activity Relationship Uncertainty Code
}

National Cancer Institute

\section{Source}

National Cancer Institute. Evaluated Activity Relationship Uncertainty Code. NCI

Thesaurus. Code C93831.

A coded value specifying whether and to what degree this evaluation or observation has been asserted to be in doubt in any way. 